\title{
The Effects of Playing Method Toward Students' Skill In Playing Mini Volleyball
}

\author{
Yuni Astuti ${ }^{1 *}$, Erianti $^{2}$ \\ 1Department of Physical Education Health and Recreation, University of Bung Hatta, Padang, \\ 2Faculty Of Sports Science, Padang State University
}

\author{
A R T I C L E I N F O \\ Article history: \\ Received 19 Desember \\ 2017 \\ Received in revised \\ form \\ 6 Januari 2018 \\ Accepted 12 Februari 2018 \\ Available online 20 \\ Februari 2018 \\ Keywords: \\ Institutional ownership, \\ Composition of independent \\ commissioners Composition \\ of board of directors, Size of \\ the company, Leverage, \\ Earnings Management
}

\section{A B S T R A K}

Based on the authors observation in the field that there are many students who do not have the skills to play mini volleyball properly. The problem is likely due to the lack of proper training method used. This study aims to reveal the influence of methods on the skills of playing mini volleyball at SD Negeri 14 Kampung Jambak Kecamatan Koto Tangah Padang City. This type of research is a quasi experiment. The population in this study were students who followed extracurricular activities mini volleyball amounted to 64 people, while the sample taken by purposive sampling, so that the sample is amounted to 35 people. The test used is a mini volleyball skill test consisting of service tests, bottom passing and passing up. Data were analyzed using t-test. Results of data analysis found that: play method gives a significant influence on the skills of playing mini volleyball students ( $\mathrm{t}$ count $=$ $13.01>$ ttabel $=2.13$ ). The average value of the initial test of the play method was obtained 50.00 and the final test was 63.65. This means there is an increase of 13.65

Copyright (C) Universitas Pendidikan Ganesha. All rights reserved.

\section{Introduction}

Early-life coaching of volleyball branches is manifested in the form of mini volleyball games aimed at children aged 9-12 years, implemented in elementary schools or clubs as a massive basic stage coaching technique. This is consistent with the coaching theory, that for the game volleyball begins at the age of 1112 years and is expected to peak at the age of 20-25 years (Suharta 2007:140). "Mini volleyball is a game played on a small pitch with 4 players each team and using simple rules", (Astuti, 2017:2).

Sports can be carried out in the learning process both intracurricularly and in self-development activities. Astuti (2017:53) "sports activities in the younger generation have the goal to change or mature the human resources". The National Education Standards Agency (BSNP) (2007: 8-9) explains that the purpose of self-development is to: "provide opportunities for learners to develop and express themselves according to the needs, talents and interests of each learner in accordance with school conditions". Thuc Mas Dao Chanh (2017:156) "students' major in volleyball of physical education department, they do not understand and use the power exercises in a scientific manner that makes them feel hard to practice strength of volleyball". Self development activities can be done in the form of extracurricular activities such as extracurricular activities mini volleyball game held in elementary school.

Based on observations made on the implementation of learning volleyball at SD Negeri 14 Kampung Jambak Kecamatan Koto Tangah Kota Padang found that teachers use the media/learning tool (ball, net, field) which are common for playing mini volleyball, without changing or modifying the learning tools and the rules. It found that the similar tools and rules came into the learning difficulties for children. For instance, the size of the ball which is similar to the adult one would be difficulties to the beginner. Then, the teacher used to use the similar approach, method and drills in teaching volleyball. With a monotonous way of teaching, It found that some children had difficulties to follow the games because they are not 
supported by their abilities. Furthermore, they would be bored easily to the volleyball and not interested to know more. For example, when they practiced service in volleyball, it can be seen that the ball is not hit through the net and then often deviated to the left and right so that the service goal to get numbers is not achieved properly. Then, at the time of passing such as passing down, the curve of the ball is not parabola or not until at a destination. Furthermore, for passing over there are many technical errors happened, for example just when the touch with the ball of his fingers is too stiff and the ball is stuck. In other words it can be concluded that the bolavoli skills possessed by students are still low. Astuti $(2017: 164)$ "volleyball is a familiar sport in the community". Zhao Qu (2015:304) "teaching and learning assessment methods to determine which to adopt". Gustavo c. c, henrique o. c, breno f. e, laura m. malheiros, pablo j. greco, and herbert ugrinowitsch. (2017:621). "in volleyball, the offensive attack correlates with a team's success".

There are many factors that cause the problems, however, the author provides method of playing at the age of elementary school children who prefer to play rather than focus on monotonous training. The play method is chosen for the enhancement of mini volleyball playing skills. This is due to the fact that the two forms of this method are in accordance with the development of children characteristics who can not be given formal of training. The purpose of this study is to see, describe and analyze the influence of playing methods in improving the skills of volleyball by students at SD Negeri 14 Kampung Jambak Kecamatan Koto Tangah Padang City.

In Primary School the game is called mini volleyball and given in intracurrikuler and extracurricular activities. Thus, it can be said that the sport of volleyball game is expected to become a branch of achievement sport that can be developed and nurtured with a hope that learners can achieve or have the skills to play volleyball well. The mini volleyball difference with the adult volleyball lies the modified rules so that it becomes simple. The basic idea of volleyball game according to Erianti (2011:2) is "put the ball into the opponent's territory through a strap in the form of a rope or net and try to win the game by turning off the ball in the opponent's swath. Demolish means to play / bounce the ball into the air before the ball touches the floor ". Thus it can be concluded that in order to win this volleyball game, a team must turn the ball on the opponent's field and the ball must pass over the net. This mini volleyball game according to Depdiknas, (2002: 68) done above: Field with a length of 12 meters and width of 6 meters and net height for the son of 2.15 meters and for the daughter of 2.00 meters. The size of the ball used is number 4, the diameter $22 \mathrm{~cm}-24 \mathrm{~cm}$ and the weight of the ball 220 grams - 240 grams. Many players are 4 people in 1 squad and 2 person reserve players. Astuti (2017:80) "this early age is a short period of child development but is a very important period for his life". Mousa K, Halaweh Rs, Al-Taieb, Ma. (2013:228) "many theories have been developed in an attempt to explain how im-agery may enhance performance".

Based on the expert's opinion, it can be clearly understood that the technique is a form of movement or a way in sports that is done efficiently and effectively to achieve the goal in the implementation of the technique, especially the skills of playing volleyball. The level of mastery of a person to a certain sports technique is a picture of mastery of his ability level of a technique. Thus, the basic technique in the game of volleyball can be interpreted as a process of physical activity or how to play the ball effectively and efficiently displayed in the form of movements such as how to perform service, passing down, passing up, bait (set-up), smash (spike) and dam (block). In the implementation adjusted to the rules of the game in effect in achieving an optimal goal. Although the skills in volleyball play include the five elements of technique as previously mentioned, but in this study, which covered only three basic techniques such as service, passing down, passing up.

Furthermore, Erianti (2009: 52) suggests that the essence of modification is "analyze and develop the subject matter by way of ordering in the form of potential learning activities so as to facilitate students in learning". Thus, when it is associated with learning basic techniques in the game volleyball, it can be interpreted that analyze and develop the basic techniques of volleyball course by way of ordering will facilitate students in practice to achieve the expected goals. The objective of the modification proposed by Lutan in Rashid (2011: 31), especially in the learning of physical education is that "a) the students get satisfaction in following the learning, b) increase the likelihood of success in participating, c) the students can do the pattern of motion correctly". To improve the students' volleyball skills in practice, it is possible for the trainer to make modifications such as modification in game form so that students get a satisfaction and can do the pattern of motion correctly. In addition, by modifying in the form of game possibilities in improving the skills of playing volleyball can be achieved well.

Some things that can be modified in developing forms of game modification to improve the skills of playing volleyball include: facilities and infrastructure needed in exercises such as ball, net and field size. Then, modifications about the rules like the length of game time and the number of players. In modifying the game there are several things to be considered such as modifications tailored to the level of motor development, cognitive, social, and affective students who learn and practice. Modification of games in teaching and training will have a positive impact on students such as giving encouragement from within a 
person who is portrayed in the desire, willingness, spirit and other encouragement in following the training process, so that participate actively, happy and passionate in following the training process. Modification of the game also makes the learning atmosphere will be more interesting and students will follow with no fear of failure in the task of motion. Game modifications also provide an opportunity for students to do engineering as a supporter in accordance with the needs of the situation being faced in the real game. The application of game modification also has the following disadvantages: 1) the correction of technique by the trainer / teacher to the player is rather difficult because the player is familiar with the techniques that have been obtained from the habit of playing, 2) if one player / student is less active or not enough in his group it will disrupt the implementation of the game.

\section{Methods}

This research is classified as a quantitative research using quasi-experiment. Mardius \& astuti (2017) "the research design used in this research is quasi experimental". The purpose of the experimental design is "to obtain information which is an estimate for information that can be obtained with actual experiments in circumstances that are not possible to control and / or manipulate all the relevant variables".

The population in this study were students who participated in extracurricular activities of mini volleyball at SD Negeri 14 Kampung Jambak Kecamatan Koto Tangah Padang City, totaling 127 students who were in grade IV, V and VI. Sampling technique in this research is purposive sampling. So that the sample in this study are students of fourth and fourth grade girls who follow extracurricular activities amounting to 35 .

\begin{tabular}{cccccc}
\hline Interval Class & Category & \multicolumn{2}{c}{ Pre Test } & \multicolumn{2}{c}{ Final Test } \\
\hline & & $\begin{array}{c}\text { Absolute } \\
\text { Frequencies }\end{array}$ & $\begin{array}{c}\text { Relative } \\
\text { Frequences }\end{array}$ & $\begin{array}{c}\text { Absolute } \\
\text { Frequences }\end{array}$ & $\begin{array}{c}\text { Relative } \\
\text { Frequences }\end{array}$ \\
$>82$ & Very Good & 0 & 0 & 0 & 0 \\
$68-82$ & Good & 0 & 0 & 3 & 18,75 \\
$53-67$ & Average & 4 & 25 & 12 & 75 \\
$39-52$ & Less & 12 & 75 & 1 & 6,25 \\
$<39$ & Poor & 0 & 0 & 0 & 0 \\
\hline
\end{tabular}

This research was conducted at SD Negeri 14 Kampung Jambak Kecamatan Koto Tangah Kota Padang.

\section{Techniques of Data Collection}

The data needed in this study is the primary data that is obtained data by executing tests on the skills of playing mini volleyball. This test consists of three items namely service test, bottom passing and passing up. After the data obtained then made into a score and summed again with the value of motion quality given by the judgment then divided into two so that can be obtained the skill of playing the mini volleyball students. Furthermore, the assessment standard is based on the average value and standard deviation generated by the group by using the reference norm according.

\section{Techniques of Data Collection}

The data needed in this study is the primary data that is obtained data by executing tests on the skills of playing mini volleyball. This test consists of three items namely service test, bottom passing and passing up. After the data obtained then made into a score and summed again with the value of motion quality given by the judgment then divided into two so that can be obtained the skill of playing the mini volleyball students. Furthermore, the assessment standard is based on the average value and standard deviation generated by the group by using the reference norm according.

\section{Research Variable}

The variables in this study consist of independent variables and dependent variables. The free variable that is the method of play and for the dependent variable that is playing mini volleyball.

\section{Techniques of Data Analysis}

Description of data and hypothesis testing in this study is to use inferential statistics with t test formula. Prior to the $t$ test analysis, firstly the requirements analysis test, ie data normality and $t$ test can only be used to test the mean difference of two samples taken from the normal population and the homogeneous group. 


\section{Result}

Based on preliminary test data before being given treatment with play method, conducted on 16 students, obtained the skills of playing mini volleyball with the highest score 65 , lowest score 41 , average score (mean) 50.00, median 53 and standard deviation ( standard deviation) 6.68. While the results of the analysis of the final test (post test) after being treated as much as 16 times found the highest score 82, the lowest score 52, the average score 63.65, median 67, and standard deviation of 7.96.

The results of the preliminary group test data analysis of the method of play method that scores the skill of playing volleyball of excellent category and good category no students have it. For the medium category are 4 people (25\%), less category is as many as 12 people $(75 \%)$ and less category once no students have it. Furthermore, for the final test result of volleyball skill with good category, no one of the students got it, good category that there are 3 Porang $(18,75 \%)$ and medium category is 12 people $(75 \%)$. Next for the category of less that is only 1 person (6.25\%) and less category once no students get it.

The test results for preliminary test data of the method group are lobservasi $0,198<$ Ltabel 0,213 can be concluded that the data is normally distributed. Furthermore, the result of testing the final test group data of the play method was found Lobservasi $0,135<$ Ltabel 0,213 . This means that the data concluded that the data is normally distributed. Based on the above description the variable is normally distributed. Based on the Lobservation (Lo) criteria smaller or equal to Ltabel (Lt) means that the population data is normally distributed, otherwise if Lobservation (Lo) is greater than Ltabel (Lt) means that the population data is normally distributed, since each probability variable satisfies the Lobservation criteria < Ltabel.

The statistical test used is t-test that is seeing the effect of the average count in the same group with a significant level of 0.05. Initial test results of mini volleyball skills of students of SD Negeri 14 Kampung Jambak Kecamatan Koto Tangah Padang by using the method of playing with the number of samples 16 people obtained the average count of 50.00 and standard deviation is 6.66 . As for the average value of the final test count (post test) is 63.65 and standard deviation is 8.01. The results of hypothesis testing are $t_{h}=$ $13.01>t_{t}=2.13$. This means that the research hypothesis is acceptable. Thus it can be concluded that the method of play gives a significant influence on the skills of playing mini volleyball students SD Negeri 14 Kampung Jambak Kecamatan Koto Tangah Padang City. Increased skill mini volleyball play is 13.65 that is from the average score of 50.00 initial test and final test to 63.65 .

From the results of the final test group of play methods, after 16 treatments were treated there was a significant increase of 13.65 against mini volleyball play skills. This is known from the initial test and the final test is from the average score of 50.00 in the initial test to 63.65 in the final test. This means that the hypothesis proposed in this study can be accepted empirically. The method of play gives a significant influence on the playing skills of mini volleyball students of SD Negeri 14 Kampung Jambak Kecamatan Koto Tangah Kota Padang. This play method is the development of game forms that lead to the mastery of basic mini volleyball techniques, from modified exercises into simplified forms of play. This means that the technical skills of playing volleyball such as bottom serve, bottom passing and passing up can be improved through the play method. Exercise through play methods is an activity involving several people, the occurrence of high social relationships and fun, and exciting. Exercise skills in mini volleyball techniques through the play method will impress that the participation of each student in the play activities will show different skill levels. Furthermore, students will be motivated and unwittingly they have done movement exercises in the implementation of the basic technique of playing volleyball repeatedly in the activity of play method.

Exercise through play methods can improve students' mini volleyball playing skills, Erianti (2009: 52) explains the essence of modification is "analyze and develop the subject matter by way of guiding it in the form of potential learning activities so as to facilitate students in learning". Thus, when associated with learning basic techniques in the game of volleyball, it can be interpreted that analyze and develop the basic technique of mini volleyball course by way of meruntunkannya so as to facilitate students in practice to achieve the expected goals.

From the method of play given the students get satisfaction in following the mini volleyball technique training, and increase the likelihood of success in participating, as well as students can perform the pattern of motion correctly. In addition, a good play method applied to elementary school students who have the characteristics of playfulness. The orientation of the practice through the play method can foster a sense of love and fun, so that this has an impact on student motivation. Motivation are all conditions that give encouragement from within a person who is portrayed as desire, willingness, and drive to perform an activity that is given with purpose. In this research, the goal to be achieved is to increase the mastery of good technique. Thus, students have the skills to play volleyball for better games. 


\section{Conclusions}

Based on the results of the test in this study, it can be concluded as follows: 1) Partially indicates institutional ownership and the composition of the board of directors has no effect on earnings management, while the composition of independent commissioners positively affects earnings management, and for the composition of the board of directors, firm size and leverage negatively affect earnings management, 2) Simultaneously indicates instisional ownership, the composition of independent commissioners, the composition of the board of directors, the size of the company and the leverage effect on earnings management. 3) Variable size of the firm dominant influence on earnings management, it is indicated by the value of Standardized efficients Beta greater than the value of Standardized Coefficients Beta other independent variables.

The management of the company should improve the compositional quality of the board of commissioners, because in this study indicates that there are still many companies whose board of commissioners concurrently holds more than one position.

While the suggestions that can be given are: 1) Enterprise management should further improve the implementation of good corporate governance, so as to improve supervision of earnings management. 2) Further research needs to add some variables and increase the number of company population to be sampled so that not only manufacturing companies but also types of service companies listed on the Indonesia Stock Exchange

\section{References}

Arsil. 2006. Perbedaan Pengaruh Latihan Teknik Elementer dan Modifikasi Permainan Terhadap Keterampilan bermain Sepakbola. (studi eksperimen pada siswa SSB UNP). Padang: Tesis Program Pascasarjana UNP.

Asep Suharta. 2007. Pendekatan Pembelajaran Bola Voli Mini Sebuah Gagasan Konseptual. Jurnal Iptek Olahraga, VOL.9, No.2, Mei 2007:139-152.

Astuti, Yuni. 2017. Pengaruh Metode Drill Dan Metode Bermain Terhadap Keterampilan Bermain Bola Voli Mini (Studi Eksperimen Pada Siswa Sd Negeri 14 Kampung Jambak Kecamatan Koto Tangah Kota Padang). Jurnal: Al Ibtida: Jurnal Pendidikan Guru Mi (2017) Vol 4 (1): 01-16.

Astuti, Yuni. 2017. Pengembangan Permainan Kolaboratif Dalam Pendidikan Jasmani Dan Olahraga Di Sekolah Dasar Untuk Optimalisasi Pembentukan Karakter. Jurnal Pendidikan Jasmani Dan Olahraga Volume 9 Nomor 2. September 2017.

Astuti, Yuni. 2017. The Power Contribution Of Arm Muscle Strength And Eyes-Hand Coordination To Volleyball Set Up Passing Skill. Jurnal Pendidikan Indonesia (Jpi), Vol. 6 No. 2, Oktober 2017.

Astuti, Yuni. 2018. Pengaruh Metode Drill Terhadap Keterampilan Bermain Bolavoli Mini Pada Siswa Sekolah Dasar. Jurnal Curricula Vol. 3 No. 1.

Bachtiar, dkk. 2001. Permainan Besar II Volleyball dan Bola Tangan. Jakarta: Universitas Terbuka.

Ditjen Manajemen Pendidikan Dasar dan Menengah. 2007. Badan Standar Nasional Pendidikan (BSNP). Jakarta: Depdiknas.

Ditjen Pendidikan TK dan SD. 2002. Buku IV Pedoman Tenis Meja, Pedoman Volimini, Pedoman Tenismini, Pedoman Senam, Pedoman Sepaktakraw. Jakarta: Depdiknas.

Erianti. 2009. Pendidikan Jasmani Adaptif. Malang: Wineka Media.

Erianti. 2011. Volleyball. Padang: Sukabina Press. 
Gustavo C. C, Henrique O. C, Breno F. E, Laura M. Malheiros ,Pablo J. Greco, And Herbert Ugrinowitsch. 2017. Predicting Factors Of Zone 4 Attack In Volleyball. Journal Perceptual And Motor Skills. Vol. 124(3).

Mardius, Ali \&ișAstuti, Yuni. 2017. Pengaruh Senam Lansia Terhadap Kebugaran Jasmani Warga Perumahan Pondok Pinang Kelurahan Lubuk Buaya Kecamatan Koto Tangah Kota Padang. Journal Of Education Research And Evaluation. Vol.1 (3).

Mousa K, Halaweh Rs, Al-Taieb, Ma. 2013, The Effect Of Movement Imagery Training On Learning Forearm Pass In Volleyball. Journal Education Vol. 134 No. 2

Rasyid, Willadi. 2011. Strategi Model Pembelajaran Penjaskesrek. Padang: Sukabina Press.

Riduwan. 2004. Belajar Mudah Penelitian untuk Guru-Karyawan dan Peneliti Pemula. Bandung: Alfabeta.

Sunarno, Agung, dkk. 2011. Metode Penelitian Keolahragaan. Surakarta: Yuma Pustaka.

Thuc Mas Dao Chanh (2017). Research And Building System Developmental Strength Exercises System By Plyometric Method For Male Students' Major In Volleyball Of Physical Education Department At An Giang University. International Journal Of Physical Education, Sports And Health 2017; 4(6).

Viera, Barbara L. dkk. 1996. Volleyball Tingkat Pemula. Jakarta: PT Rajagrafindo Persada.

Yusuf, A Muri. 2005. Metodologi Penelitian. Padang: UNP Press.

Zhao Qu (2015: ) A Discussion On Assessment Method And Learning Approach. Education Journal. Vol. $3(5)$. 